\title{
6 Thus Spoke Zarathustra: Communication of mood or nihilistic self-parody?
}

While it would be a too extreme hypothesis to claim that it is with his Thus Spoke Zarathustra that Nietzsche rises or falls, the work is central to Nietzsche's endeavour as he himself repeatedly insists. In the foreword to $E H$, Nietzsche singles out $Z$ as "the real book of the mountain air" (Large 2007, 4), ${ }^{1}$ repeatedly refers to Zarathustra throughout the text, and finally associates what he already said through Zarathustra, i.e. the discovery of the life-denying nature of Christian morality ("God", "true world” etc.), with a radical cut of history into two halves (KSA 6, 373-374). Whatever one thinks of the hyperbolic excesses of $E H$, it is imperative to see the truth behind it. For if $Z$ is due to its poetic character ignored and Nietzsche read only for his more accessible philosophical writings, as is the dominant practice in Anglophone philosophy, then I do not see how one can avoid the view that Nietzsche should not primarily be considered a philosopher at all given the weight he himself attached to the work. Any attempt to turn Nietzsche into a "philosopher" despite this runs utterly counter to Nietzsche's intentions, his highest hopes as well as his laughter which is to no small extent directed at academic philosophy (cf. Reents 2015, 236). For my project, which is to throw light on Nietzsche's criticism of religion through his communication of mood, $Z$ is an indispensable source. I have already shown that communicating mood plays an important role in Nietzsche's critical project in the writings of his free spirit -period. How does $Z$ fit into this picture?

The following engagement is not to be understood as a comprehensive commentary: $Z$ speaks for itself. The reader will find no overview of the vast scholarly literature on $Z$, but instead a focused discussion on the communication of mood. The main question, through which I approach the work, is to what extent $Z$ challenges and/or moves further than his preceding writings when it comes to affective communication. In other words, I explicitly question to what extent $Z$ can be used to problematize the interpretation advanced thus far in this study.

I begin by examining the two most important presuppositions for approaching $Z$. The first one is to recognize the place of $Z$ within Nietzsche's writings and to approach the work with his critical projects in mind. The second presupposition concerns the appreciation of the affective dimension of the text. After having furthermore discussed the tone of $Z$, I will seek to cast more light on the character of Nietzsche's communication of mood through a discussion of Zarathustra's speech Upon the Isles of the Blest, which is among his most important speeches that touch on the theme of religion. Thereafter I will in the final sections consider if there is self-parody in the text of $Z$, and if there indeed is self-parody in the text

1 “das eigentliche Höhenluft-Buch” (KSA 6, 259). 
whether it is best read as an internal critique of the "use of mood" within the text or rather as an important part of the communication of mood.

\subsection{The place of $Z$ within Nietzsche's works}

In a letter to Franz Overbeck from 7 April 1884, Nietzsche speaks of $D$ and $G S$ as prefiguring $Z$ and that those two works can even be read as commentaries on $Z$ (KGB III/ 1, Bf. 504). ${ }^{2}$ That Nietzsche singles out precisely these two works is significant; as I have shown a strategic use of a mood of expectation plays an important role in both. What makes Nietzsche's use of mood special, which is specifically evident in GS, is how playful it is, i.e. how Nietzsche exemplifies the mood. In this regard, it is also worth noting what Nietzsche writes in a sketch for the foreword of the second edition of GS. There, writing about the original edition of GS, he specifies one sense in which $G S$ can be said to prefigure $Z$ and that is the playful approach to all that is sacred. ${ }^{3}$ However, it should be added that the first formulations of the experience of being able to gain a philosophical freedom of being above all human things, an experience of mountain air [Höhenluft], which eventually lead to $Z$, stem from the period directly preceding the publication of $\mathrm{HH}$ and that aspects of the new experience are already present in that work in embryonic form. Undoubtedly, some elements of $Z$ can be traced even further back. In a letter from 29 August 1886 to his then publisher Fritzsch, Nietzsche himself states that a presupposition for understanding his Zarathustra is to be acquainted with all of his previous writings (KGB III/3, Bf. 740). ${ }^{4}$ Such statements about the works preceding $Z$ cement the perception that $Z$ occupies a central and unique position among Nietzsche's writings. They also point to the need to approach $Z$ with an understanding of the concerns of the preceding texts, and then most of all the immediately preceding ones.

2 'Beim durchlesen von 'Morgenröthe' und 'fröhlicher Wissenschaft' fand ich übrigens, daß darin fast keine Zeile steht, die nicht als Einleitung, Vorbereitung und Commentar zu genanntem Zarathustra dienen kann. Es ist eine Thatsache, daß ich den Commentar vor dem Text gemacht habe" (KGB III/1, Bf. 504). Nietzsche repeats the same claim in a letter to Resa von Schirmhofer (cf. KGB III/1, Bf. 510). 3 "Vorbereitung zu Zarathustras naiv-ironischer Stellung zu allen heiligen Dingen (naive Form der Überlegenheit: das Spiel mit dem Heiligen)” (NL1885-86, 2[166], KSA 12, 150).

4 "Das Wesentliche ist, daß, um die Voraussetzungen für das Verständniß des Zarathustra zu haben (ein Ereigniß ohne Gleichen in der Litteratur und Philosophie und Poesie und Moral usw. usw. Sie dürfen mir's glauben, Sie glücklicher Besitzer dieses Wunderthiers! -) alle meine früheren Schriften ernstlich und tief verstanden sein müssen; insgleichen die Nothwendigkeit der Aufeinanderfolge dieser Schriften und der in ihnen sich ausdrückenden Entwicklung." (KGB III/3, Bf. 740) Of course, Nietzsche's words to his publisher are best understood against the background that he wanted to see all his writings published again with new forewords. Of course, not all of Nietzsche's writings prefigure $Z$ to as great an extent as $D$ and GS. Still, it is certainly helpful, as Nietzsche suggests, to understand his philosophical development or what should perhaps more properly be termed his development into a new kind of philosopher. 
Against this background, and especially when one is all too aware that the dominant trend in Anglophone scholarship still is to ignore context, one should applaud Julian Young when he insists on the importance of understanding and keeping Nietzsche's previous texts in mind when approaching Z. Young is certainly correct when he claims that the sayings of Zarathustra all too easily become "oracular ink-blots on which to project one's favourite philosophy” (Young 2006, 105). Now, however, it is necessary to ask what is meant by approaching $Z$ through the preceding works. Is it enough to recognize continuities in the philosophical contents of $Z$ and the preceding writings? Or is it perhaps essential to recognize the role of affective communication in those writings in order to understand what $Z$ is about? With this last question in mind, the limits of Young's approach can be made apparent. Young focuses only on the content of $Z$, and specifically on Zarathustra's teaching. Young's central claim is that his procedure of interpreting $Z$ not only helps to understand Zarathustra's sayings, but that they become "in most cases, clear and unambiguous" (Young 2006, 105). This is a very bold claim. Young wisely avoids commenting on the central teachings of $Z$, the Übermensch ${ }^{5}$ and Eternal Recurrence, which are notoriously ambiguous. However, this very choice of avoiding those ideas as if they did not exist, and instead focusing on a few sayings by Zarathustra that purportedly support a communitarian reading of Nietzsche's philosophy of religion, begs the question if Young himself is not guilty of seeing in $Z$ what he wants to see. Before advancing an interpretation of the content of $Z$ one should therefore ask, why in the first place it is the case that the work provokes interpretation, why it is that each philosophical interpreter comes to his own conclusions about what kind of a human is an Übermensch, what Will to Power is, and whether and in what sense Eternal Recurrence can be affirmed.

The central teachings of Zarathustra remain vague and unspecific. What MarieLuise Haase writes about the Übermensch in an oft-cited article that deservedly has become something of a classic, namely that Zarathustra's vision of a new kind of human remains a surface for projection, ${ }^{6}$ applies as much to the rest of his visionary teachings. Already in his afterword to $Z$, Giorgio Colli contends that $Z$ reveals in a particularly striking way that for Nietzsche the content is not that which is essential about his communication (KSA 4, 411) and that one therefore seeks in vain for a theory of the Übermensch, Eternal Recurrence or Will to Power (KSA 4, 412). The consequence of accepting Colli's viewpoint is that the teachings of Zarathustra cannot be translated into the strict language of philosophical concepts. Indeed, Colli's words can be read as a warning to refrain from the temptation of systematizing the content of Zarathustra's teaching. That most interpreters still go straight for the content or themes of Zarathustra's teaching, is proof enough that Colli's contention

5 As much as I like Parkes' translation Overhuman (Parkes 2005), I leave the term Übermensch untranslated (except in direct citations from Parkes) for the sake of clarity. This is common practice in Anglophone scholarship.

6 "Die Vision Zarathustras vom neuen Menschen bleibt für uns ein Vexierbild" (Haase 1984, 244). 
has not been taken with the gravity it deserves. This is all the more true of Anglophone scholarship, which has concentrated on Zarathustra's teaching understood precisely as the philosophical doctrines of Übermensch, Eternal Recurrence and Will to Power (e.g. Lampert 1987 and Rosen 1995). ${ }^{7}$ Undoubtedly, studies that focus solely on this supposed "content" can be enlightening, in that they often present intriguing interpretations. At their best, such interpretations might even be of independent philosophical interest. Nevertheless, it is very problematic from the perspective of Nietzsche-scholarship when the results are presented as Nietzsche's ideas and not as those of the interpreter.

The alternative approach to $Z$ that is taken here is to let Zarathustra's teachings remain unspecific. Young's claim that Zarathustra's words become unambiguous when one takes account of Nietzsche's writings prior to $Z$ has to be rejected as too bold, but also as missing the point. Young's claim is too bold, because it is far too easy to get lost in the labyrinth that is $Z$, even when one has a good grasp of the preceding writings. It also misses the point, because it does not recognize the possibility that Zarathustra's teachings might be ambiguous on purpose. To be absolutely clear: To let Zarathustra's words remain unspecific does not mean to leave them uncommented. Paying attention to the affective dimension of Nietzsche's communication helps understand why the "teachings" are so unspecific. Here we come to the second presupposition of approaching $Z$; paying attention to the affective dimension of the text. To gain clarity about the matter, it is therefore necessary to revisit Colli's afterword.

\subsection{Giorgio Colli on $Z$ as communication}

Firstly, it is necessary to differentiate Colli's contention that the content is not that which matters most in $Z$ from an extreme view that Nietzsche ridicules in $E H$. Nietzsche there mentions the author and critic Karl (Carl) Spitteler, a later Nobelprize recipient, who according to our philosopher treated $Z$ as nothing more than an exercise in style in a review in which he furthermore expressed the wish that Nietzsche would in the future care more about the content (KSA 6, 299). Nietzsche counters this critique by going on to explain that the book is to be understood as speaking of and as expressing through language experiences that differ not only from ordinary experiences but essentially from all that has been, i.e. that it is the

7 The only significant exception in Anglophone scholarship that I know of is Kathleen Higgins' monograph on $Z$, which pays due attention to the fictional nature of the narrative (Higgins 1987). Unfortunately, those aspects of her work that are of most concern to us have had a negligible impact on Anglophone scholarship. This is especially regrettable, because Higgins asks the right question about the place of mood in Z; namely, whether Nietzsche's use of mood in the work is best understood as open-ended communication of mood or as an attempt to manipulate the reader's mood (cf. Higgins 1987, 112). 
first language for a series of new experiences (KSA 6, 300). Importantly, Nietzsche's explanation culminates in his discussion of good style as expression and communication of inner states (KSA 6, 304). So if we follow Nietzsche's line of thought, the "truth" that is brutalized in Spitteler's review is that the style of $Z$ is in itself meant to express the inner experiences that $Z$ is about. The philosophical content, Zarathustra's teachings, are to be understood as translations of such inner states. As such, the philosophical value of $Z$ would consist in knowledge in and of such states, insofar as they are beneficial to philosophical enterprises. It follows that the communication of such experiential knowledge depends to a great extent on how the text embodies what it speaks of, and with this starting point in mind, we can return to Colli.

Colli explicitly distances his contention from the view that $Z$ would be a purely stylistic achievement. Quite to the contrary, he treats $Z$ as a particular attempt at communication. As such, Colli focuses on that which Nietzsche purportedly wants to communicate (KSA 4, 412), namely the Dionysian essence (KSA 4, 413) or simply Dionysian immediacy (KSA 3, 414). Unremarkably, Colli is at pains to describe this Dionysian immediacy. He associates it with spontaneity, immediacy of life beyond consciousness; in short an experience of the primordial ground of being [UrGrund]. Still, he is adamant to stress that Dionysian immediacy is not an inaccessible mystical experience, but accessible to everyone. Between the lines of $Z$, he asserts, moments of Dionysian immediacy can be glimpsed and perhaps even a complex, lasting state of being (KSA 4, 414). This indefiniteness can of course be excused, if one accepts Colli's assertion that Dionysian immediacy can only be expressed as vision. In this view, Nietzsche's attempt to communicate an experience of the Dionysian explains the expressive language of Zarathustra, which instead of rising to the level of conceptual thought remains pictorial and symbolical (KSA 4, 412). At this point one is tempted to ask about the philosophical value of Nietzsche's communication, given that in Colli's interpretation the experience that $Z$ speaks of can never be clarified. There is, however, a still more pressing question.

What evidence is there that Nietzsche intended $Z$ to express Dionysian immediacy? It is of critical importance to note at this stage that it is one thing to claim that Nietzsche meant $Z$ to express an extraordinary kind of experience, and another to interpret $Z$ as actually expressing such an experience. It is yet another thing to acknowledge that Nietzsche wanted his readers to believe that $Z$ expresses a Dionysian experience. In $E H$, Nietzsche clearly leads the reader to makes this connection between $Z$ and Dionysus, and between the Dionysian and the air of the heights. According to Nietzsche, $Z$ is the result of overflowing power. It is a singular achievement where the Dionysian became deed in the text, and where Dionysus became reality in the type of Zarathustra (cf. KSA 6, 343-345). Here too one finds a description of the language of $Z$ as a return to immediate pictorial nature. Nietzsche speaks of 
a "return of language to its natural state of figurativeness" (Large 2007, 72). ${ }^{8}$ One can therefore conclude that Colli's interpretation follows Nietzsche's own "interpretation" in $E H$ heel to heel.

Unfortunately, there is no earlier evidence external to the text of $Z$ that would explicitly support or refute the interpretation that Nietzsche intended to establish a connection between Zarathustra and Dionysus all along. There are no decisive clues to be found in the Nachlass nor are there any in the letters. We have however already seen, i.e. I have already shown, that it is problematic to rely exclusively on $\mathrm{EH}$ when interpreting the affective dimension of Nietzsche's writings (see section 4.2 and especially section 4.2.6). Although there are no reasons to raise any fundamental objections against Colli's interpretation at this point, one should nevertheless ask if there is not more to be said of Nietzsche's communication of mood in $Z$ than that it is an attempt to communicate Dionysian immediacy. This question is especially pertinent, when one takes account of Nietzsche's playful use of a strategy of raising expectations in the preceding writings.

Despite concluding the discussion about the relevant evidence with such a sceptical question, and irrespective of the initial misgivings that can be read into the question, Colli's afterword is the best available starting point for a more thorough investigation of Nietzsche's affective communication in $Z$, simply because of his emphasis that the work can fruitfully be approached as a specific attempt at communication. Colli is arguably also right to emphasize that even if $Z$ can hardly be called a philosophical work (KSA 4, 412), at least judged against the way philosophy has been understood, it is in harmony with Nietzsche's philosophical project (KSA 4, 413) and is to be understood as an attempted renewal of philosophy (KSA 4, 414). It is a different question if Colli's understanding of Nietzsche's philosophical project stands critical scrutiny, and to this question I will return in the following discussions: for now it suffices to explore the consequences of his view. Colli suggests that Nietzsche thought taking account of the Dionysian experience would transform the way philosophy is done, but adds that it is too early to judge whether $Z$ can achieve that purpose (KSA 4, 414). To this last point, one might also add Colli's observation that $Z$ is not aimed exclusively at philosophers (KSA 4, 414), but at all those who might be susceptible to its communication. The broader aim would then seem to be a general affective reorientation that should enable the renewal of culture. The logical consequence of accepting this picture as starting point is, as Colli suggests (KSA 4, 414), that the ultimate value of the affective communication of $Z$ can only be seen if and when the reception of the work initiates or significantly contributes to a cultural or philosophical renewal. That, however, need not mean that one has to wait, perhaps indefinitely, for such a Nietzschean cultural renewal to happen, before one can say anything definite about Nietzsche's intentions regarding the communication of $Z$. After all, the basic idea is familiar from the preceding works: affective reorien-

8 "Rückkehr der Sprache zur Natur der Bildlichkeit” (KSA 6, 344). 
tation is a presupposition for a lasting renewal of thinking. In the case of the preceding works, it has been possible to uncover significant hints about the direction in which Nietzsche aims, so it is reasonable to assume that the same applies to $Z$. Precisely wherein the philosophical, as well as the broader, value of Nietzsche's affective communication (in $Z$ ) potentially resides can only be considered once the nature of this communication has been discussed in more detail. I begin this task by addressing the tone of the work.

\subsection{The tone of $Z$}

Whatever the precise nature of the experience that Nietzsche attempts to communicate, it is mediated through the tone of the work. In $E H$, Nietzsche emphasizes that one must above all heed the tone of Zarathustra: "Above all you have to hear properly the tone that comes out of this mouth, this halcyon tone" (Large 2007, 4; KSA 6, 259). There, Nietzsche explicitly speaks of the supposedly slow tempo of the words that flow through the mouth of Zarathustra, which he associates with the stillness before a storm, and goes on to quote the beginning of the passage Upon the Isles of the Blest as example: "The figs are falling from the trees..." (Large 2007, 5; KSA 6, 260) That chapter is central when it comes to understanding Nietzsche's attack on religion in $Z$, which means that I will return to it soon enough, but what now requires pointing out is that what Nietzsche seeks to exemplify by quoting the passage is the joy of Zarathustra, the depth of his joy [Glückstiefe], which in order to save the consistency of the metaphor one would have to translate as his "height of joy", from which his words fall like ripe fruits. In exemplifying such joy, Zarathustra's words must be interpreted as words of persuasion, words of exhortation. It is in this context that Nietzsche himself asks, whether Zarathustra is not one who tempts: a seducer? (KSA 6, 260; cf. Large 2007, 5) An important clue for interpreting the aim of such affective communication in $Z$ can be found in his answer. Interestingly, Nietzsche does not answer his own question directly. Instead, he evades it by merely pointing out that not only does Zarathustra's communication differ from that of saints, redeemers and their kind, but that he "is" different because he does not want believers. Here again, Nietzsche reiterates the by now familiar maxim that if one is to follow him/Zarathustra, one has to follow one's own self. In what sense is this answer so enlightening?

The answer shows that Zarathustra is without a doubt a seducer, one who through his words tempts the reader by suggesting that he himself dwells in a "high mood" of joy and that by listening to him one might perhaps gain the strength to rise to one's highest potential. Yet his words both explicitly and implicitly make it clear that he is a very special kind of seducer, who cannot be followed unless one is willing to think for oneself. How does Nietzsche accomplish the task of both tempting the reader and simultaneously keeping him/her at a distance? 
Zarathustra's speech On Reading and Writing cannot be overlooked when trying to answer this question (Z I 7, KSA 4, 48). It is most tempting to read this speech as meta-commentary on $Z$ : more than any other speech or saying it invites such a reading. The speech famously begins by introducing the metaphor of writing with blood. That writing with blood means to write out of one's most personal experience, is evident from the way in which the speech quickly turns from the topic of reading and writing to Zarathustra's own experience, his way of living and life-wisdom. ${ }^{9}$ However, the fact that Zarathustra is a fictional character begs the question in what sense the text of $Z$ can be a translation of experience: this should be a warning against a too simplistic reading. In this regard, the last words that still directly connect to the explicit discussion of writing with one's blood are particularly instructive, as they would perfectly seem to fit Nietzsche's own style as practised both in GS and $Z$ : "The air thin and pure, danger near, and the spirit filled with a joyful wickedness: these things go well together." (Parkes 2005, 35; Z I 7, KSA 4, 48) What follows is something of a demonstration of this joyful yet mocking mood that is meant to reflect Zarathustra's own way of being. It is admittedly near at hand to collapse the distinction between the character Zarathustra and Nietzsche when encountering sayings like the following one, yet it is precisely the impossibility of equating Nietzsche and Zarathustra that creates the distance that is essential to his communication:

\footnotetext{
You look upward when you desire uplifting. And I look downward because I am uplifted. Who among you can laugh and be uplifted at the same time?

Whoever climbs the highest mountains laughs about all tragic plays and tragic wakes. (Parkes 2005, 36; Z I 7, KSA 4, 49)
}

The significance of the quoted passage is heightened by the fact that Nietzsche chose it as motto for part three of $Z$ (Z III, KSA 4, 192; cf. Young 2006, 107). What at first sight might seem to be nothing more than yet another instance of Nietzsche's off-putting self-aggrandizement, this time through the mouth of Zarathustra, is arguably something far more complex. Indeed, one might even go as far as to suggest that the reader is presented with something of a joke. The perspective of which Zarathustra speaks is one which allows him to see even himself (and his own tragic teaching) from above. As the final words of the speech announce: "Now I am light, now I am flying, now I see myself beneath myself, now a God dances through me.” (Parkes 2005, 36; Z I 7, KSA 4, 50) One could of course read these words as speaking about an experience of Dionysian immediacy following Colli, or "a habitation of the perspective of Dionysian pantheism” to borrow Young's words (Young 2006, 111). Yet the fact is that the name Dionysus does not appear in $Z$ one single time. The same applies to the term

9 This interpretation is furthermore supported by Zarathustra's contention that it is not easy to understand another's blood (Z I 7, KSA 4, 48), which closely resembles Nietzsche's recurrent complaints that no one in his time is capable of understanding those of his experiences, which matter most to him. 
Dionysian [dionysisch]. While this does not mean that the terms should under no circumstances be used to interpret Zarathustra's words, it is important to note that he is clearly describing a state of heightened self-awareness, which is not comparable to the ecstatic rush [Rausch] associated with the Dionysian in his early work (e.g. in $B T)$.

I therefore find it far more promising to base the interpretation on the intriguing hint within the text that Nietzsche precisely here where he has Zarathustra speak about writing with blood, about expressing one's inner states, lets his protagonist engage in self-parody. On the one hand Zarathustra's words express the distance between the character Zarathustra as teacher and those to whom he speaks, but on the other hand suggests that a specifically self-parodic distance is essential to his teaching, to his role as teacher. This vision is reflected in the tone of the work. Throughout $Z$, Zarathustra teaches but simultaneously laughs at his own teaching, which forces the recipient of his teaching to return to his own self, to make up his/her own mind. In other words, Zarathustra cannot be followed. This initial sketch can be fleshed out by paying careful attention to Zarathustra's curious teaching about the Übermensch as a replacement to the dead God.

\subsection{Upon the Isles of the Blest}

Zarathustra's speech to his disciples Upon the Isles of the Blest (KSA 4, 109), seems to rely on the communication of a mood of expectation in a manner familiar from his preceding works. That which is expected is the Übermensch. This new hope is of course already introduced in Zarathustra's prologue [Vorrede] (KSA 4, 14), but the crucial difference is that there Zarathustra speaks to the people, not to a select group of disciples. There his teaching fails and not even the vision of the last man, of a type of human incapable of reaching beyond its limited horizon, that Zarathustra conjures up to scare the people make them interested in hearing his words about the Übermensch (KSA 4, 19). Speaking to those whom he calls his brothers [meine Brüder] (KSA 4, 109), knowers [ihr Erkennenden] (KSA 4, 110) and friends [ihr Freunde] (KSA 4, 110), Zarathustra employs a more sophisticated art of persuasion.

To his disciples Zarathustra presents his teaching as an intervention in the history of religion. In other words, Zarathustra's directs his words at a specific kind of hearer, who is in some significant sense bound to this religious history. Although Nietzsche already acquaints the reader with the trope that God is dead at the very beginning of $Z$, Zarathustra in fact does not explicitly mention this "event" in his speech to the people. When speaking to his disciples, by contrast, he presupposes that they have acknowledged that God is dead: "Once one said 'God' when one looked upon distant seas; but now I have taught you to say: Overhuman." (Parkes 2005, 73; KSA 4, 109) Thus, Zarathustra begins to teach a redirection of religious desire as a transformation of the highest hopes that mankind has known. Just as in GS, 
and especially in the fourth book, Nietzsche here plays with a mood of expectation for a yet higher state of being, now named Übermensch, but this time the situation is entirely fictional. Zarathustra is presented as trying to communicate a mood to his disciples, which should enable joyful striving as he stresses that the Übermensch will not appear, unless given birth to.

It is crucial that Zarathustra ascribes to his disciples the power to create the Übermensch, as his decisive objection against religious hopes was that the highest hope should be within reach, within the possible (KSA 4, 109). Against this background, one might present the following interpretation of why Zarathustra teases his hearers by cautioning that they might not succeed. Thereby Zarathustra seeks to infect his hearers with the lust to create the Übermensch by suggesting that it indeed is a heroic task worthy of the efforts of the most ambitious spirits, and in this context it makes sense for him to proclaim that if they do not have the strength to transform themselves, they can at least become fathers and forefathers of the Übermensch through their efforts (KSA 4, 109). However, this latter suggestion might also be read as a suggestion that there is no such thing as an Übermensch and never will be. This begs the question, whether the Übermensch in Zarathustra's teaching serves any function other than that of a replacement for God, and if not, whether this teaching does not contradict the basic thrust of Nietzsche's criticism of religion, which as I have sought to clarify is about reorienting affect in a way that does away with the need for religion, which necessarily also entails doing without replacements.

In this regard, it is instructive to point out what role the idea of the Übermensch plays in $Z$ as a whole. In parts one and two of $Z$, the Übermensch is arguably central to the narrative: Zarathustra's teaching to his disciples revolves around the concept. This changes in part three, in which the Übermensch is not explicitly mentioned until the very end, and then only as a passing reminiscence (KSA 4, 248; cf. Haase 1984, 240). Finally, in part four it would seem that the idea is only the target of parodic laughter (cf. Haase 1984, 241-242). Already in the first two parts there are hints that the Übermensch is nothing more than a useful tool meant to be thrown away when no longer needed; a metaphorical expression of the longing of the free spirit, who is still guided by religious feelings.

In his speech to his disciples Upon the Isles of the Blest, Zarathustra mockingly questions whether they can create a god and instead bids them to use their power to create the Übermensch. In part one, however, Zarathustra himself speaks of how he once directed his passion toward other worlds, and in doing so created a God for himself (KSA 4, 35). In other words, creating a God is perhaps no task at all. Likewise, Zarathustra teaches his disciples that all talk of Eternity is just metaphorical, just allegory, and adds that the poets lie too much (KSA 4, 110). Yet Zarathustra "admits" that he himself is a poet. ${ }^{10}$ It is of no small consequence that he in this context spe-

10 “die Dichter lügen zu viel” (KSA 4, 110). "Dass die Dichter zuviel lügen? - Aber auch Zarathustra ist ein Dichter” (KSA 4, 163). 
cifically mentions both gods and overhumans [Götter und Übermenschen] as poetic creations (KSA 4, 164), of which he has become tired (KSA 4, 165). These examples again force us to confront the question about parody and self-parody in $Z$, and how they relate to Nietzsche's affective communication within $Z$ as well as more broadly.

\subsection{The question concerning self-parody in $Z$}

Is there self-parody in $Z$ ? Are Zarathustra's teachings undermined by the self-parody within the text? How would such self-parody fit into the picture that I have thus far painted of Nietzsche's affective communication? It is remarkable that the two living scholars who take $Z$ most seriously and have written major monographs to advance their interpretations, Claus Zittel and Paul Loeb, present diametrically opposed answers to the first two questions. While both provide strong critiques of those who would consign $Z$ to the dustbin and still save Nietzsche as philosopher (Loeb 2010, 207-213 and Zittel 2011, 13-20), their respective interpretations couldn't differ more: they are utterly irreconcilable.

Claus Zittel argues in favour of the thesis that the text of $Z$ parodies all the doctrines that Zarathustra teaches and effectively all "hopes" (e. g. Zittel 2011, 104, 128, 213 and 223). In this view, there are not only occasional hints of self-deconstructive parody scattered throughout the text, but the very design of $Z$ ends in self-destructive parody with nihilistic consequences. Zittel goes as far as to claim that a nihilistic interpretation of $Z$ is the only viable one; the only one that conforms with textual evidence. Paul Loeb, on the other hand, bluntly denies that there is any self-parody in $Z$ (Loeb 2010, 242). Loeb insists that there is no evidence in $Z$ that the kind of parody initiated by the protagonist of the text, by Zarathustra, would involve self-parody. In this view, the parody of $Z$ is instead directed only at everything that had been taken seriously until Zarathustra's teaching, while Zarathustra's teaching is itself a life-affirming counter-ideal to all ascetic tendencies.

In more recent Anglophone contributions to the discussion on $Z$ it has become more of a rule rather than an exception to question whether there is any significant self-parody in the work (e.g. Seung 2005; Young 2006; Young 2010). I will therefore begin by examining the grounds for that view. As the strongest statement of the view is to be found in Loeb's work, and since he articulates his reasons most clearly, I will at first concentrate on his categorical rejection of the possibility that there might be self-parodistic elements at work in $Z$.

Loeb notes that the final aphorism of GS, which is almost identical to the opening of $Z$, is entitled Incipit Tragoedia (GS 342, KSA 3, 571; cf. Loeb 2010, 240). This title is indeed significant, and it is certainly possible to read it, following the understanding of tragedy and comedy developed in aphorism 1 (GS 1, KSA 3, 369-372), as suggesting that Zarathustra is a teacher of the purpose of existence. Any naive or straightforward interpretation in that direction is however made problematic by 
Nietzsche's comment on "Incipit Tragoedia" in the foreword to the second edition of $G S$. There Nietzsche singles out the title of the aphorism as an example of the playful, treacherous spirit of $G S$ and suggests that what really is about to begin is parody: incipit parodia (GS Preface 1, KSA 3, 346). In order to exclude the possibility of readings that take this to suggest that $Z$ is at least in some significant sense a work of self-parody, Loeb claims that the incipit parodia of the foreword has falsely been interpreted to imply a practice of self-parody (Loeb 2010, 240 -242). Against scholars who rely on the foreword to justify a self-parodistic reading, Loeb points out that "nowhere in his further explanation does Nietzsche imply that the new kind of parody begun by his protagonist Zarathustra will be self-parody" (Loeb 2010, 242). Loeb, however, overlooks that the foreword is not the only addition made by Nietzsche to GS that is significant in this regard. Loeb completely ignores the more decisive addition: the motto, which makes absolutely clear that a "Master" who cannot laugh at himself is someone who one must laugh at (cf. GS Title page, KSA 3, 343).

Of course, it might seem possible to interpret the motto to mean that one has to be able to laugh at one's past self from one's present position. So in $Z$ the life-affirming Nietzsche would laugh at his former self who held on to ascetic ideals. Such an interpretation, that would save Loeb's intention, is nevertheless implausible as it is hard to reconcile with the text of $Z$. There is no doubt that Nietzsche's Zarathustra highly values the capacity to rise above tragedy and to laugh at oneself, to view oneself from above, from a distance (cf. KSA 4, 150). In any case, the decisive evidence about self-parody is to be found within the text, and already on the basis of the passage referred to above one cannot exclude the possibility that there are at least hints in the texts that allow a reading emphasizing self-parodic elements. If there is no reason to conclude that there is no self-parody in $Z$, could there be reasons to consider the entire work self-parody?

\subsection{Claus Zittel's challenge: Nihilistic self-parody?}

Claus Zittel's thesis that the text of $Z$ not only at times undermines the teachings of its protagonist but culminates in nihilistic self-parody is worth interrogating, since his reading is by far the most sophisticated and powerful attack on all interpretations that read $Z$ as in one way or another opening up a future to desire or at least the possibility of creating a desirable future as a free spirit. While I start by acknowledging and emphasizing the relative merits of Zittel's interpretation, I here seek to show that paying careful attention to the question of Nietzsche's communication of mood shows the limits of his interpretation.

Zittel's starting point is solid as a rock: he sets out from the observation that the complex composition of $Z$ betrays a high degree of aesthetic reflection. What is so striking about the composition of $Z$, the aesthetic calculation [ästhetische Kalkül] (cf. Zittel 2011, 11-12) that the title of his monograph alludes to? The text of $Z$ abounds with intertextual references (to the literary tradition; above all the Bible) 
and intratextual references (to passages within Z) (Zittel 2011, 74). With this starting point one can hardly disagree. More controversially Zittel argues that it follows from the parodic treatment of the literary tradition in $Z$ that it can be identified as a "late" work that doesn't go beyond the tradition that it parodies but merely points toward the end of that tradition. Similarly, and even more controversially, Zittel argues that part four serves an analogous function within the work, in the sense that the parody that predominates in the first three parts turns into self-parody in the fourth part, which merely points towards the end of Zarathustra's/Nietzsche's philosophical project in failure (Zittel 2011, 126-128 and 223).

Let us for now focus on less far-reaching conclusions that can be drawn from recognizing the complexity of the composition of $Z$, and examine the evidence about the more radical theses later. According to Zittel, acknowledging that the text of $Z$ exhibits a high level of reflection precludes treating $Z$ as the expression of some kind of primordial experience of immediacy (Zittel 2011, 113-114). Zittel does not mean to say that Nietzsche would not invite such a reading, but that the good reader does not let him- or herself be carried away by Nietzsche's language, his seductive words of affirmation, but listens carefully to the cautions and warnings present in the text (Zittel 2011, 93-94). On this point, Zittel explicitly takes to task those scholars who follow the paradigmatic example of Colli and rely primarily on passages and quotes from $E H$ to justify their interpretations (Zittel 2011, 92-93). What immediacy there is in $Z$ is in this critical view a carefully crafted and illusory immediacy. ${ }^{11}$ In other words, Zittel presents his study as nothing less than an all-out attack on interpretations that privilege the seductive surface of Nietzsche's text, and particularly as an intellectualist corrective to emotionalist readings. In this regard, he especially targets interpretations that take Zarathustra's teachings (Übermensch, Eternal Recurrence) at face value, and instead seeks to show in what questionable and deceptive manner those teachings are presented in the text.

While I agree wholeheartedly with Zittel's critique insofar as it is highly problematic to rely solely on $E H$ as a guide to Nietzsche's affective communication and/or to take Zarathustra's doctrines at face value, ${ }^{12}$ it is necessary to ask to what extent his critique hits its primary target. To be specific, one can question if Zittel does not misread Colli at least in one important respect. After all, Colli also cautions against thinking that $Z$ is about the doctrines Übermensch, Eternal Recurrence and Will to Power. Be that as it may, there is certainly a fundamental problem in Colli's view of $Z$ as an expression of Dionysian immediacy. To recognize that whatever $Z$ expresses, the expression is mediated through reflection, is enough to reject a naive understanding of Nietzsche's affective communication, as a communication of ecstatic Dionysian affirmation [Rausch]. Contra Zittel, it in no way follows that Nietzsche's

11 Cf. Zittel's aptly named chapter “Fingierte Unmittelbarkeit” (Zittel 2011, 173-180).

12 Such readings abound. Recently, for example, Franco has written of the Übermensch as Nietzsche's “new ideal” as if that were unproblematic (Franco 2011, 162-170). 
affective communication is nothing more than a clever deception that the good reader sees through. Rather than hindering a critical reading, being attuned to the joyful and playfully treacherous mood of $Z$ arguably makes an even further reaching critique possible. The warning signs that Zittel speaks of cannot escape the reader, who pays attention to Nietzsche's affective communication. So when Zittel asserts that Zarathustra actually preaches suspicion against all doctrines (Zittel 2011, 104), one need only ask why this would contradict the joyful affirmation that Zarathustra nonetheless equally promotes. Is it not precisely the union of sceptical sentiment and joy, after all, which characterizes Nietzsche's ideal mood?

In fact, a careful reading of $E H$ reveals that a similar manner of communication is at work there. No passage exemplifies this better than the one which he begins by proclaiming that he knows his privileges as author [Vorrechte als Schriftsteller] (KSA 6, 302). While it would seem that Nietzsche only writes about his right to choose those for whom he writes in a manner quite familiar from his other writings (e.g. BGE 30, KSA 5, 48), he is also issuing a warning to his readers. With characteristic hyperbole, Nietzsche proclaims that he comes from heights where no bird has ever flown, and that only those who can rise to his heights and who are therefore related to him can understand him. In the midst of praising his books as the proudest and finest that there are, he suddenly and mischievously adds that his books now and then reach "the highest thing that can be achieved on earth, cynicism" (Large 2007, 39; KSA 6, 302). Cynicism as the highest peak that can be reached? This if anything is a warning and yet it is a warning told in a language of affirmation familiar from $Z$.

Returning to $Z$, Zittel certainly does a good job in showing what he terms the deceptive character of the visions that Zarathustra plays with and teases his disciples with. ${ }^{13}$ The critical question is in what sense, if any, this complicates the question concerning Nietzsche's communication of mood. Does the deconstructive self-parody that some interpreters find in the text necessarily work against the viability of Nietzsche's philosophy and the project of affective reorientation or does it paradoxically play a more constructive role within it? In seeking to answer this question the fourth book of $Z$ is decisive, since Nietzsche there confronts his protagonist with various challenges, above all a parody of the teachings of the Übermensch and Eternal Recurrence, which arguably culminates in self-parody (cf. Zittel 2011, 128-132). In the following section, I focus solely on this most striking example of deconstructive parody within book four of $Z$; namely the Ass Festival [Eselsfest].

13 What Zittel calls the "trügerische Character des verbreiteten Verheissungsoptimismus" (Zittel 2011, 207). 


\subsection{Deconstructive parody in the Ass Festival}

Thus Spoke Zarathustra begins with a reminder that God is dead (KSA 4, 14) and it is against this background that Zarathustra teaches the Übermensch (e.g. KSA 4, 109). Zittel wryly notes that instead of being presented with the Übermensch in part four, the reader is presented with the "enthronement" of an Ass (Zittel 2011, 195). A number of "higher men" have gathered at Zarathustra's cave in the mountains; and they awaken his hopes for he sees in them his own hopes. There is something about them that bothers Zarathustra still, so he leaves his cave to converse with his animals. The higher men are merry [fröhlich], which appears to him a sign of becoming healthy, but although they have learned to laugh, he tells his animals that their laughter is not akin to his (KSA 4, 386). Whatever their faults, Zarathustra seeks to shake off his unease. He speaks to his heart that indeed the higher men are on the path to health; that they are convalescents [Es sind Genesende!] (KSA 4, 387). Then, suddenly, Zarathustra hears a strange commotion from his cave, which had fallen silent, and a fragrant scent of incense reaches his nose (KSA 4, 388). Thus begins the Ass Festival, the interpretation of which is decisive to settle the question concerning self-parody, and therefore for the interpretation of $Z$ as a whole (cf. Higgins 1987, 227-228). ${ }^{14}$

When Zarathustra returns to his cave he finds the higher men on their knees engaged in what he later calls a play [Schauspiel] (KSA 4, 391), a parody play of religious rites. What is parodied, however, appears to be more than Christian tradition; specifically it seems as if Zarathustra's teaching of the Übermensch, which is indissociable from his teaching of affirmation, were the main source of laughter: the higher men mockingly praise the wisdom of the Ass, whom they call their God. The Ass, however, only ever answers with I-A, with affirmation. ${ }^{15}$ Zarathustra interrupts the

14 While Higgins poses many of the right questions, her reading of book four and particularly the Ass festival as "Menippean satire" modelled after Apuleius' Golden Ass is a prime example of overinterpretation. There is no evidence that Nietzsche primarily based his narrative on this one source, the understanding of which would uncover the meaning of the spectacle. (Cf. Higgins 1987.)

15 "Amen! Und Lob und Ehre und Weisheit und Dank und Preis und Stärke sei unserm Gott, von Ewigkeit zu Ewigkeit!- Der Esel aber schrie dazu I-A. Er trägt unsre Last, er nahm Knechtsgestalt an, er ist geduldsam von Herzen und redet niemals Nein; und wer seinen Gott liebt, der züchtigt ihn.- Der Esel aber schrie dazu I-A. Er redet nicht: es sei denn, dass er zur Welt, die er Schuf, immer Ja sagt: also preist er seine Welt. Seine Schlauheit ist es, die nicht redet: so bekommt er selten Unrecht.- Der Esel aber schrie dazu I-A. Unscheinbar geht er durch die Welt. Grau ist die Leib-Farbe, in welche er seine Tugend hüllt. Hat er Geist, so verbirgt er ihn; Jedermann aber glaubt an seine langen Ohren.- Der Esel aber schrie dazu I-A. Welche verborgene Weisheit ist das, dass er lange Ohren trägt und allein ja und nimmer Nein sagt! Hat er nicht die Welt erschaffen nach seinem Bilde, nämlich so dumm als möglich?- Der Esel aber schrie dazu I-A. Du gehst gerade und krumme Wege; es kümmert dich wenig, was uns Menschen gerade oder krumm dünkt. Jenseits von Gut und Böse ist dein Reich. Es ist deine Unschuld, nicht zu wissen, was Unschuld ist.- Der Esel aber schrie dazu I-A. Siehe doch, wie du Niemanden von dir stössest, die Bettler nicht, noch die Könige. Die Kindlein lässest du zu dir kommen, und wenn dich die bösen Buben locken, so sprichst du einfältiglich I-A.- Der Esel aber schrie dazu I-A. Du liebst Eselinnen 
spectacle violently and interrogates the higher men, who only provide joking answers to his question why they put up such a show (KSA 4, 390-392). According to one prominent interpretation, the higher men are laughing at themselves and at their own convictions both through their festival and in their answers (Young 2006, 115), which delights Zarathustra, who understands the necessity of periodical release from the seriousness of living according to his teaching (Young 2006, 116). Young goes as far as to claim that the "Ass Festival" shows that the "festival, the rebirth of the life-affirming Greek festival, remains at the centre of Nietzsche's thinking” (Young 2006, 117). Such a reading fits his narrative about a communitarian, religious Nietzsche, who was all the time mostly concerned with creating new communal festivals. Characteristically, Young completely overlooks an important part of the narrative and that is Zarathustra's initial reaction, which is certainly not one of delight.

Instead of joining in on their fun or directly praising the higher men, Zarathustra interrupts them, screams at them and demands answers. It also seems as if he were not pleased at all with the answers he receives as he loudly cries "Oh you buffoons, all of you, you jesters! Why do you disguise and conceal yourselves from me!” (Parkes 2005, 276; KSA 4, 393) and claims that they really want to return to the comforts of a childish faith. After thus castigating the higher men there is a pause, and it is highly significant that only after this pause there is a shift in Zarathustra's attitude toward the higher men. It is as if he has calmed down and regained his composure. Only now, finally, Zarathustra tells the higher men that they delight him. His words about the need for new festivals, which follow, are specifically addressed to the higher men: it seems to him that they need some old Zarathustra-clown and new festivals to cheer them up, and that such rites as the worship of an ass that he just witnessed are really only invented by those who are on their way to health. (Cf. KSA 4, 393394.)

Zittel, who unlike Young builds his interpretation around Zarathustra's initial reaction, speculates that Zarathustra is upset at the higher men, because they not only parody religious traditions but his own teaching (Zittel 2011, 183-184). To put it bluntly: the higher men laugh at Zarathustra (cf. Higgins 1987, 227-228). More specifically, it would seem that precisely those teachings meant to enhance life after the death of God, above all the Übermensch and the associated idea of the highest affirmation of life (i.e. Eternal Recurrence), are the target of ridicule. In other words, the narrative returns to Zarathustra's first attempt to communicate his teaching, where the people of the city mock him. Zittel therefore concludes that Zarathustra's teaching has failed and that he himself realizes that he has no power over his doctrines, which leads to resignation and the self-parodic characterization of himself as just some old comic clown or jester [Zarathustra-Narr] (KSA 4, 393; Zittel 2011, 183-184). That Zarathustra has no power over his doctrines, however, is not much

und frische Feigen, du bist kein Kostverächter. Eine Distel kitzelt dir das Herz, wenn du gerade Hunger hast. Darin liegt eines Gottes Weisheit.- Der Esel aber schrie dazu I-A.” (KSA 4, 388-389) 
of a problem, if one should take his words seriously about not wanting followers and about following oneself. In other words, one might claim that even if Zarathustra's explicit teaching might have failed, Nietzsche's narrative only gains power when the authority of the teacher is deconstructed. Such an interpretation could point to the fact that the narrative does not end with the Ass Festival and what else Nietzsche recounts about that night, and that instead it ends when Zarathustra early in the morning leaves the higher men behind in his cave, sets off on his own (guided by a vision of "his children"), with his own work in mind (KSA 4, 408). Be that as it may, the Ass Festival does pose a challenge to all readings that rely on Zarathustra's status as teacher, as he arguably fails to live up to his own words.

What is most alarming, following the interpretation developed in this chapter, is that we initially witness a failure on Zarathustra's part to laugh at his own doctrines. Was not Zarathustra supposed to be able to view himself from above and to laugh at himself? One might of course claim that Zarathustra is not seriously shocked and instead only acting. This option is implausible, because the evidence that Zarathustra has serious problems with the higher men is both clear and abundant. What is particularly interesting is that Zarathustra now and again leaves his cave, where the higher men are gathered, in order to get fresh air, i.e. to be alone with himself (and his animals). "Do they not smell good?" (KSA 4, 369), he asks his animals about the higher men. In their presence he cannot breathe free air, his mountain air. Read against this background, the narrative that leads to the Ass Festival takes on new meaning.

Again, Zarathustra has escaped from his cave into the free air (cf. KSA 4, 378) but this time he is lured back as he realizes no noise emerges from his cave and instead there is a fragrant scent in the air: "his nose smelled a fragrant smoke and incense, as if from burning pine-cones" (Parkes 2005, 273; KSA 4, 388). Both fascinated and alarmed by this scent, he rushes back to the entrance of his cave. Whatever hopes Zarathustra might have had turn out to be illusory. It is not the case that the higher men smell any better than before, but that they are burning incense. It is even worse than that; not only are they burning incense, they are worshipping an ass. Is this how the higher men should raise themselves even higher? Has Zarathustra taught them to rise higher through spectacle, through a kind of collective intoxication?

The word intoxication is not entirely out of place here. In the text there are even hints that wine also plays a part in the celebrations. Firstly, we are told that some of the higher men, the two kings to be precise, have brought a supply of wine to Zarathustra's cave: as much as an Ass can carry [einen ganzen Esel voll] (KSA 4, 353-354). Secondly, the narrative itself becomes drunk, when the celebrations begin to approach midnight. The text clearly hints that there is no certainty about what took place that night ("as some storytellers believe", "There are even those who say" or 
"Now it may have been this way or otherwise”, Parkes 2005, 278; KSA 4, 396). ${ }^{16}$ One of the things that "are told" about the night is that the Ass danced (cf. "I should only believe in a God who knew how to dance”, Parkes 2005, 36), ${ }^{17}$ because it too had been given wine to drink (KSA 4, 396). Interestingly, though it is earlier suggested that Zarathustra himself only drinks water (KSA 4, 353), he also appears drunken as midnight approaches ([wie ein Trunkener]; KSA 4, 396; cf. Zittel 2011, 196). An easy, all too easy, solution to the interpretative challenge that these references to intoxication pose is to associate the wine with Dionysus and the celebrations all in all with the ecstasy [Rausch] of the birth of tragedy (cf. BT 1, KSA 1, 28-30; Colli, KSA 4, 412-413) and then to deduce that we witness the rebirth of life-affirming festival (cf. Young 2006). Perhaps such an interpretation would be feasible, were it not for the mature Nietzsche's recurring critique of intoxication and artificially produced high feelings.

Zittel summarizes Nietzsche's key point thus: Only tired human beings, only those who are tired of life [lebensmüde], require special means of intoxication (Zittel 2011, 196-197). While this viewpoint also finds expression in $Z$ (e.g. KSA 4, 353), aphorism 86 of GS is particularly instructive in this regard, not least because one could go as far as to extract the following exclamation as the motto of Nietzsche's critique: "Does he that is enthusiastic need wine?" (Kaufmann 1974, 142; GS 86, KSA 3, 443-444). ${ }^{18}$ The importance of the aphorism for the work done here does not derive from the fact that Zittel draws heavily on it in order to justify his interpretation: Indeed, the aphorism is actually apt to problematize his entire reading. The aphorism, of the theater, is so important because it reveals the real reason behind Nietzsche's rejection of artificially induced ecstasy. There, Nietzsche openly expresses his disgust at those artists who cater to people who would not have any idea of higher moods [höheren Stimmungen], were it not for the existence of intoxicating means in the shape of either art or wine. They need an art of intoxication that without sufficient reason raises feeling to a higher level. When the artist lowers himself to serve their instincts, the strongest thoughts and passions are made to serve cheap intoxication, which is the only height that a public incapable of dwelling in high moods can reach. Those like himself, who know high moods from their own experience, have no need of such arts and are appalled by such spectacles. (GS 86, KSA 3, 443-444).

Aphorism 86 of GS represents no rejection of the value of high moods. To the contrary, it is a defence premised on the need to distinguish artificially induced intoxication from those high moods that are philosophically significant; that are an essential fruit of the philosophical life. In his interpretation of $Z$, Zittel fails to take into

16 "wie manche Erzähler meinen", "Es gibt sogar Solche die Erzählen”, "Diess mag sich nun so verhalten oder auch anders" (KSA 4, 396).

17 "Ich würde nur an einen Gott glauben, der zu tanzen verstünde." (KSA 4, 49)

18 “Was braucht der Begeisterte Wein!” (GS 86, KSA 3, 443-444) See also Nietzsche’s auto-biographical advise to all spiritual natures to abstain from alcohol (KSA 6, 280-281). 
account that Nietzsche distinguishes desirable "higher states" from a kind of intoxication that he vehemently criticizes and rejects, and only because of this failure can Zittel claim that Nietzsche's communication of mood is nothing more than artful deception. Still, Zittel's misreading is valuable precisely because it raises the question how the two can be distinguished. In this regard, it is of utmost importance to note that it is not possible to distinguish the two on the level of the text. Whatever high moods Nietzsche presents Zarathustra as experiencing, these cannot simply be interpreted as direct translations of Nietzsche's own experiences of philosophically significant moods. It is simply not enough to point out, as Higgins does, that Zarathustra is "presented as one who engages in honest introspection" (Higgins 1987, 114). In other words, there is reason to reflect on the decisive role that Nietzsche leaves to the reader, who has no means to draw a clear line between the drunkenness of the Ass that supposedly danced and Zarathustra's seeming drunkenness, which is not limited to specific visions (e.g. KSA 4, 396) but pervades his rhetoric.

\subsection{Zarathustra, the Ass and nihilism}

Given the role of the Ass in the fourth part of $Z$, it is not unreasonable to see the Ass as an embodiment of the greatest objection to Zarathustra's teaching. In this regard, the most solid starting point is Jörg Salaquarda's contention in an oft-cited article: The Ass is the actual antipode of Zarathustra (Salaquarda 1973, 205; cf. Zittel 2011, 183 and Young 2006, 115). What matters here is as much the relation as the opposition between the two. The Ass says I-A to everything, the Ass affirms all, and is this not exactly what Zarathustra's Übermensch does? Zarathustra himself teaches in the third book, in the speech On the Spirit of Heaviness, that only the Ass has learned to say yes to everything. "Always to say Yea-haw--that only the ass has learned, and whoever is of his spirit!” (Parkes 2005, 168; KSA 4, 244) Logically, it would then seem that if the Übermensch is to affirm everything, he or she has to have the spirit of an Ass. However, the very same speech by Zarathustra contains the hint that the affirmation that he teaches is in fact first and foremost an affirmation of the individual, of personal tastes (yes-saying) and distastes (nay-saying), and only then through this affirmation, through this specific individual perspective, an affirmation of all. ${ }^{19}$ This requires a light spirit, not the kind of heavy spirit, which he associates with the Ass. As he states, one does not learn to fly unless one follows oneself: "This--is just my way:--where is yours?", he asks, and adds: "For the way--does not exist!" (Parkes 2005, 169; KSA 4, 245) Once again, Zarathustra emphasizes the role of the recipient of his words, and this fits the thesis that Nietzsche's communication of

19 To a great extent, my reading on this point aligns with Deleuze's influential interpretation that the Ass lacks the capacity to say no, which makes his yes a false yes that is akin to Christian renunciation of the self in its acceptance of carrying the weight of the "world" or the "real" (Deleuze 1983, 178 and 180 -182; cf. Hödl 2009, 450). 
mood in $Z$ is meant to aid the reader to return to him- or herself, in the sense that any heightening of feeling is only possible through reflection on one's own experience.

Against this background, one can object to the way in which Zittel tries to make the most out of an easily overlooked self-description in book four in which Zarathustra speaks of himself as the one who gives wings to asses ([Der den Eseln Flügel giebt], KSA 4, 367). Namely, he reads the passage as a thinly veiled admission of the character of Zarathustra's teaching. After all, Zittel reasons, Nietzsche critically characterizes the artist who seeks to induce intoxication as one who "gives the mole wings” (Kaufmann 1974, 142; GS 86, KSA 3, 444), so should the image of giving wings to asses not be read in this light? According to Zittel, Nietzsche/Zarathustra suggests nothing else than that those who believe his teaching and allow themselves to be carried away by his style are asses (Zittel 2011, 197) ${ }^{20}$ Zittel furthermore claims that the image of winged asses makes all the metaphors of flying in $Z$ laughable (Zittel 2011, 197). While Zittel is certainly right in his claim that Nietzsche's use of metaphors of heights and flying cannot always be read as only being constructive when one takes account of Nietzsche's critique of intoxication (Zittel 2011, 197), this is not enough to conclude that the playful treatment of the metaphors, which given their centrality in the self-characterizations of Zarathustra amounts to self-parody, is entirely deconstructive. Importantly, the ass-metaphor is also not as exclusively negative as Zittel portrays it. In the speech On Reading and Writing, Zarathustra answers those who say that life is hard, that in some sense all of us are asses: "We are all of us pretty sturdy asses and she-asses” (Parkes 2005, 36; KSA 4, 49). Turned back on Zarathustra, and when one adds that he then goes on to speak about how he learned to fly, he is not only the one who gives wings to asses but was himself once an ass. The metaphor allows one to think that one leaves the ass within behind when one grows wings. There is of course still the possibility of thinking of Zarathustra as still primarily an ass; now perhaps a flying ass (cf. Zittel 2011, 198). In this regard, one must simply ask what difference it makes and refer to Zarathustra's "motto": "what does it matter!” (Parkes 2005, 278; KSA 4, 396).

Be that as it may, there is one reason above others to resist Zittel's conclusion that the text of $Z$ presents the reader with the alternative of either approaching the text emotionally and following Zarathustra into intoxication, or approaching the text purely intellectually and revealing Nietzsche's true message; the nihilistic despair beneath the surface. I think it can be shown that Nietzsche's communication of mood is not meant to trick the reader into ecstatic affirmation and thus turn the reader away from a confrontation with nihilism, and that therefore Zittel's reading is far too bound to the perspective it tries to get rid of. Indeed, Zittel's interpretation is best read as a corrective to Colli, who claimed that $Z$ is an expression of Dionysian immediacy and that the character of this emotional communication of $Z$

20 "Zum ersten meint er, daß es Esel sind, die ihm glauben und sich an seinem Stil berauschen" (Zittel 2011, 197). 
makes a nihilistic interpretation of the text impossible (KSA 4, 415). In a less known introduction to $Z$, Colli goes as far as to compare the effect of the book to a drug and to a magic potion (Colli 1993, 92). ${ }^{21}$ Colli thus reads $Z$ as if it were primarily crafted to induce the kind of ecstasy celebrated in BT, i.e. as if Nietzsche's thinking on mood had not advanced at all in the years between the publication of that rather immature work and $Z$. Thus, Colli overlooks that even in $E H$, where Nietzsche connects Zarathustra and Dionysus, he speaks of the experiences expressed in $Z$ as "new experiences", not as experiences already known to the ancient Greeks or experiences accessible to anyone (cf. KSA 6, 299-300). Instead of marking a return to $B T$ and to a celebration of collective intoxication, $Z$ is best interpreted as a sign of that development of Nietzsche's thinking on mood, which leads him to rethink the Dionysian as a philosophical mood and finally to describe himself as a disciple of the philosopher Dionysus (see chapter 7). This is a mood, which ideally allows one to affirm that which is problematic and questionable: it is essentially a generalization of the joy of sceptical questioning. In other words, this ideal mood allows one to enjoy rather than avoid "nihilism".

What after all is nihilism for Nietzsche other than a magic word used to conjure visions of impending catastrophes and thus to scare off certain kinds of reader? In the end, it turns out that Zittel's interpretation is in this regard not primarily based on textual evidence from within $Z$, but on a remarkably rigid interpretation of the death of God (Zittel 2011, 104; 134-136; 223). Again, Zittel's starting point is solid enough. According to him, Nietzsche does not only have the Christian God in mind when writing that God is dead. Rather, all the old gods are dead. All values have become suspicious. All values have become questionable. This then is nihilism. Thus far, it is hard to disagree with Zittel, and it is rather Zittel's interpretation of the psychological consequences of accepting that God is dead which is problematic as it does not conform to the available evidence. His key claim is that since there is no absolute truth, all new values and ideals are illusions that cannot be believed. In other words, they cannot motivate. Zittel's assumption, which Nietzsche does not share, is that if there is no "absolute truth" there is no truth at all, and that my truth, your truth and our truths do not matter. To justify his reading, according to which the death of God inevitably leads to a cultural logic of self-destruction [Selbstaufhebung], Zittel relies exclusively on a simplistic reading of the opening aphorism of book five of GS that "explains" what it means that God is dead (cf. chapter 5, section 5.7 of this study). In this light, Zittel asserts that all passages in Nietzsche's oeuvre that suggest a desirable future should be interpreted as deceptive, subjective illusions. ${ }^{22}$ Zittel furthermore asserts that he can integrate all of Nietzsche's futureoriented statements into his interpretation, which he contrasts with the supposed in-

21 "Daß dieses Buch wie eine Droge wirkt, ist eine mehr oder weniger verbreitete Tatsache, und wenn seine Gegner dies gerne bestreiten, belügen sie sich selbst.” (Colli 1993, 92)

22 "Alle Zukunfts-bejahenden Stellen lassen sich nun als lediglich subjektive Illusionen einstufen, mit welchem z.B. 'Der Freie Geist' sich über den objektiven Untergang hinwegtäuscht.” (Zittel 2011, 136) 
ability of interpreters who favour an "optimistic" Nietzsche-interpretation to integrate his warnings and pessimistic visions (Zittel 2011, 136-137).

I do not know much about "optimistic" Nietzsche-interpretations, but the interpretation advanced here argues that Nietzsche counted with a radically open future. In this view, both Nietzsche's "optimistic" and "pessimistic" visions of the future are understood as part of a strategy of communication. ${ }^{23}$ Aphorism GS 343 is a good example, as it does not present definite answers, but instead forces the reader to make up his/her mind. Neither Nietzsche's promises nor his warnings about future possibilities should be understood as deterministic statements of what is to come. Nietzsche time and again qualifies his visions with scepticism, e.g. by asking who could tell what is to come (e.g. D 453, KSA 3, 274). If Nietzsche thinks "absolute truth" died with God, as Zittel plausibly suggests in his interpretation, then there is even less ground for deterministic claims about the future. That there is no absolute truth, that God is dead, is precisely the presupposition for thinking the future as radically open, and in this context Nietzsche's enticing visions are meant to have an impact on the future. Recognizing that God is dead does not make high moods impossible. Instead, it opens new possibilities, not least the possibility of living one's life as a philosophical experiment and as a result of a different mode of life reach new heights of feeling. For Nietzsche, mood matters more than ever after the recognition that God is dead. Nietzsche's own efforts suggest that while nihilism does not imply an end to creativity, "high moods" gain in importance as sources of motivation when religious ideals lose their credibility. As there cannot be a universal ideal, there must be individual ideals, some of which however might be more compelling than others. This explains why the task of purifying feeling is so important to Nietzsche, and why the highest hopes of mankind should be fundamentally transformed according to the motto "become who you are", not simply redirected. It also explains why the distinction between (religious, Wagnerian or alcoholic) ecstasy and philosophical moods is so important, since only the latter have lasting value for the philosopher. In short, the death of God leads the philosopher to reflect on the question of an ideal philosophical mood.

23 Curiously, Zittel does in a footnote (Nr. 415) intended to support his thesis that Zarathustra's doctrines should not be believed, mention approvingly that Marie-Luise Haase has questioned whether Zarathustra's talk of the death of God is a message to the reader that is meant to be understood as a statement of fact (Zittel 2011, 204). As much as he emphasizes Nietzsche's aesthetic strategies, Zittel seems unable to accept that the message that God is dead might be yet another strategic test, perhaps to lure the ones to whom he speaks to reorient their striving and/or to become who they are. After all, it was none other than Zarathustra who was originally supposed to announce that God is dead in GS (cf. KSA 14, 256). 


\subsection{Conclusion}

I have suggested that the teaching of Zarathustra aligns with the project of GS (i.e. become who you are [werde, der du bist], cf. KSA 4, 297) and provided evidence from within the text that Nietzsche's communication of mood supports this project. To conclude, I will present further support for my reading from Nietzsche's letters, and from a short look forward to his next books, which in no way support Zittel's reading about Nietzsche's philosophical project coming to a nihilistic end in $Z$. Nietzsche himself had no interest in directly explaining what he sought to accomplish through $Z$, but in his letters one can nevertheless find clues that support this reading. Admittedly, all of these letters predate the completion of the fourth book, but they should nevertheless be taken heed of. In an unsent letter addressed to an admirer named Paul Lanzky, dated April 1884, provoked by the admission of Lanzky that he does not see Nietzsche's goals, Nietzsche rhetorically and mockingly asks if he really has to "descend", to lower himself, to explain his Zarathustra. ${ }^{24}$ Although Nietzsche does not quite go as far as to "explain" his Zarathustra, he does go some way towards answering the question about the goals of $Z$. First he bluntly writes that he wanted to encourage himself with the work. ${ }^{25}$ Only after that does he add something more generally encouraging: that all those men and women who strive for their own goal, will gain strength from reading $Z .^{26}$

Nietzsche writes to Köselitz in a similar yet even more sceptical manner in September the same year. In that letter Nietzsche attests that he personally considers the value of $Z$ to depend on its function as a book of edification and encouragement, but adds that the book must seem obscure and pathetic to everyone (KGB III/1, Bf. 529). ${ }^{27}$ That Nietzsche himself took this encouragement-effect of $Z$ quite seriously is beyond doubt, as he explicitly mentions it in a number of letters. ${ }^{28}$ More than anything, however, these letters show Nietzsche's recurring doubts about his ability to reach through to his readers through his texts. Although Nietzsche's communication of mood arguably reaches a new height in $Z$, especially in the use of artistic means, the letters still speak of the work as being only an entrance to his philosophy. That prompts one to ask about the relation of $Z$ to those two works that at least in

24 "Wollen Sie mich reizen, Mehr zu sagen, als ich Lust habe? - - Oder soll ich zu der absurden Rolle hinabsteigen, meinen Zarathustra (oder seine Thiere) erklären zu müssen? Dafür, denke ich, werden irgendwann einmal Lehrstühle und Professoren dasein.” (KGB III/5, Bf. 506a)

25 "Bemerken Sie doch: ich habe mich mit diesem übermenschlichen Bilde ermuthigen wollen." (KGB III/5, Bf. 506a)

26 "Alle Menschen aber, die irgend einen heroischen Impuls in sich haben zu ihrem eigenen Ziele hin, werden sich eine große Kraft aus meinem Zarathustra herausnehmen.” (KGB III/5, Bf. 506a)

27 "Erbauungs- und Ermuthigungs-Buch" ... "dunkel und verborgen und lächerlich für Jedermann" (KGB III/1, Bf. 529).

28 E. g. to Franz Overbeck: "Dieser Zarathustra ist nichts als eine Vorrede, Vorhalle - ich habe mir selber Muth machen müssen” (KGB III/1, Bf. 494). Cf. to Malwida von Meysenbug: "Eine Vorhalle zu meiner Philosophie - für mich gebaut, mir Muth zu machen” (KGB III/1, Bf. 498). 
Anglophone scholarship are considered his main works, Beyond Good and Evil and On the Genealogy of Morals (Leiter 2002, xii; cf. Clark and Dudrick 2012, 2-3; cf. Janaway 2007, 1).

In $E H$ Nietzsche himself writes that having finished $Z$, the yes-saying part of his task was finished and that the works that follow have a more direct destructive intent (KSA 6, 350). Does this mean that Nietzsche is no longer concerned with the communication of mood in his later works? Though Nietzsche's own distinction is useful, one should take care not to read it in a way that leads one to overlook continuities. In other words, Nietzsche's philosophical writing does not fundamentally change after $Z$, but he does expand on it significantly. So if his project came to a nihilistic end in that book nihilistic ends do not mean much. In this regard, a letter to Jacob Burckhardt is particularly instructive. In 1886, Nietzsche implores Burckhardt to read $B G E$ even if its message is the same as that of Z. ${ }^{29}$ Arguably, this also applies to $G M$, which despite superficially seeming to be even further away from $Z$ than $B G E$ is without a doubt a continuation of the philosophical concerns of the preceding works. Indeed, what has changed most in these works is the form, as Nietzsche tones down the use of artistic means in order to return to a more direct form of expression. There is therefore arguably more to be learned from Nietzsche's discussions about feeling-states than from his "use of mood" in these later works. That is of course not to say that communication of mood would play no significant role in the works, but that as Nietzsche's playful "use" of mood is not as apparent and mostly follows the pattern of the preceding works it is not of as great interest to us here as his more direct communication; and specifically his statements about an ideal mood.

A case in point is $B G E$, which in this regard is nothing less than a bridge to Nietzsche's final works. ${ }^{30}$ There one can observe a by now familiar strategy of communication at work: that of suggesting a high mood of affirmation (as a specifically philosophical mood) and tempting the reader with visions of the embodiment of this mood in a human being. Nietzsche himself suggests that his book is nourishment for a higher type of human: a dangerous book for all except for those few higher souls who perhaps have the strength to rise to heights above tragedy and who are therefore able to read the book as a challenge for themselves (BGE 30, KSA 5, 48-49). Throughout the text, Nietzsche acts as seducer [Versucher]; most notably by introducing his

29 "Bitte, lesen Sie dies Buch, (ob es schon dieselben Dinge sagt, wie mein Zarathustra, aber anders, sehr anders -)." (KGB III/3, Bf. 754; cf. KGB III/3, Bf. 768)

30 I have already discussed the 1887 edition of GS, which is very much in tune with the message of $B G E$. When it comes to $G M$, Christopher Janaway has in a boldly argued monograph study sought to cast light on the affective dimension of the text, which he analyses in terms of "affective reorientation" (Janaway 2007). Janaway is certainly correct about the big picture; that Nietzsche also in GM seeks to engage the reader's emotions and to persuade the reader to reorient his or her affects. While Janaway's results align with mine in that respect, I do think that there are serious problems with his study if read on its own, as he relies almost exclusively on a speculative, philosophical interpretation of the text of $G M$. 
idea of the philosophers of the future both as a test and temptation (BGE 42, KSA 5, 59), as the only hope worth the name in a time of decadence (BGE 203, KSA 5, 126 128). Without disregarding or in any way downplaying the fact that Nietzsche is brutally honest about what he considers absolutely necessary "immoral" preconditions for the emergence of these philosophers, ${ }^{31}$ above all an acute feeling of social distance [Pathos der Distanz], it is for our purposes more important to note that his main emphasis is elsewhere. Nietzsche explicitly focuses on a by-product of the feeling of social distance, a desire for ever higher states of feeling within the soul (BGE 257, KSA 5, 205). ${ }^{32}$ In other words, the feeling of social distance is for him not valuable in itself, but only as a means to an end; to far greater feelings of distance.

The decisive question is why Nietzsche places such emphasis on the heightening of feeling, on high moods? One possible answer is that Nietzsche thus in fact intends to open the way towards a new religion based on experiences of ecstasy. So even as Nietzsche again implies that Christian moral feelings stand in the way of a higher type of life, one might still think that Nietzsche's ideal mood is in some significant sense religious. Such a reading might seem tempting, because Nietzsche's statements about the matter in $B G E$ are quite vague, and because he at the end of the book reintroduces Dionysus into his philosophy (BGE 295, KSA 5, 237-239). So while this concise excursus to $B G E$ has provided support for my reading of $Z$, insofar as it shows that Nietzsche is still very much concerned with the question of mood, it has also raised the question about the precise nature of Nietzsche's ideal mood. Specifically, the question is whether it is best characterized as a religious state, and that is the question of the following chapter.

31 Throughout his discussion about the philosophers of the future, Nietzsche employs a vocabulary of breeding [Züchtung], speaking of inheritance and blood, and these ideas inform his vision of the social preconditions of the emergence of that higher type. In this regard, he speaks of the necessity of a strict order of rank, and consequently of some form of slavery, in the sense of people to be treated as tools (cf. BGE 257, KSA 5, 205).

32 "Distanzerweiterung innerhalb der Seele selbst", specifically "die Herausbildung immer höherer, seltener, fernerer, weitgespannterer, umfänglicherer Zustände, kurz eben die Erhöhung des Typus 'Mensch', die fortgesetzte 'Selbst-Überwindung des Menschen', um eine moralische Formel in einem übermoralischen Sinne zu nehmen" (BGE 257, KSA 5, 205). 